\title{
Energy balance model applied to pasture experimental areas in São Paulo State, Brazil
}

Gustavo Bayma-Silva, Antonio Heriberto de Castro Teixeira, Daniel de Castro Victoria, Sandra Furlan Nogueira, Janice Freitas Leivas, et al.

Gustavo Bayma-Silva, Antonio Heriberto de Castro Teixeira, Daniel de Castro Victoria, Sandra Furlan Nogueira, Janice Freitas Leivas, Daniel N. Coaguila, Valdo Rodrigues Herling, "Energy balance model applied to pasture experimental areas in São Paulo State, Brazil," Proc. SPIE 9998, Remote Sensing for Agriculture, Ecosystems, and Hydrology XVIII, 99981C (25 October 2016); doi: 10.1117/12.2242043

SPIE. Event: SPIE Remote Sensing, 2016, Edinburgh, United Kingdom 


\title{
Energy balance model applied to pasture experimental areas in São Paulo State, Brazil
}

\author{
Gustavo Bayma-Silva*a, Antônio Heriberto de Castro Teixeira ${ }^{a}$, Daniel de Castro Victoria ${ }^{b}$, Sandra \\ Furlan Nogueira ${ }^{\mathrm{a}}$, Janice Freitas Leivas ${ }^{\mathrm{a}}$, Daniel N. Coaguila ${ }^{\mathrm{c}}$, Valdo Rodrigues Herling ${ }^{\mathrm{d}}$ \\ ${ }^{a}$ Embrapa Monitoramento por Satélite, Campinas, SP, Brazil; ${ }^{b}$ Embrapa Informática e Agropecuária, \\ Campinas, SP, Brazil, ${ }^{\mathrm{c}}$ São Paulo State University, Hydraulic and Irrigation Division, Ilha Solteira, \\ SP, Brazil, ${ }^{\mathrm{d} S a ̃ o ~ P a u l o ~ S t a t e ~ U n i v e r s i t y, ~ F a c u l t y ~ o f ~ A n i m a l ~ S c i e n c e ~ a n d ~ F o o d ~ E n g i n e e r i n g, ~}$ \\ Pirassununga, SP, Brazil.
}

\begin{abstract}
The Simple Algorithm for Evapotranspiration Retrieving (SAFER) was used to estimate biophysical parameters and the energy balance components in two different pasture experimental areas, in the São Paulo state, Brazil. The experimental pastures consist in six rotational (RGS) and three continuous grazing systems (CGS) paddocks. Landsat-8 images from 2013 and 2015 dry and rainy seasons were used, as these presented similar hydrological cycle, with 1,600 mm and 1,613 $\mathrm{mm}$ of annual precipitation, resulting in 19 cloud-free images. Bands 1 to 7 and thermal bands 10 and 11 were used with weather data from a station located near the experimental area. NDVI, biomass, evapotranspiration and latent heat flux $(\lambda \mathrm{E})$ temporal values statistically differ CGS from RGS areas. Grazing systems influences the energy partition and these results indicate that RGS benefits biomass production, evapotranspiration and the microclimate, due higher LE values. SAFER is a feasible tool to estimate biophysical parameters and energy balance components in pasture and has potential to discriminate continuous and rotation grazing systems in a temporal analysis.
\end{abstract}

Keywords: SAFER, pasture, grazing systems, biomass, evapotranspiration, latent heat flux, sensible heat flux, soil heat flux

\section{INTRODUCTION}

The Cerrado biome occupies 2,039,243 $\mathrm{km}^{2}$ in the central portion of Brazil. Pasture areas increased from 541,495 $\mathrm{km}^{2}$ to $600,832 \mathrm{~km}^{2}$ between 2002 and 2013, 26.5\% and 29.5\% of the biome ${ }^{1,2}$, respectively. Bovine cattle rearing at the Cerrado biome occurs predominantly under continuous systems, which is the reason why pasture degradation has become a big problem that causes economic and environmental losses to the industry. The identification and recovery of such areas could favor production gains, e.g. higher carbon stocks in the soil. This anthropic land use has been investigated in order to discriminate the energy exchanges in rotational and continuous grazing system areas. A rotational system allows soil and animal management, with pasture fertilization and animal rotation in different paddocks. Continuous grazing systems do not adopt this management, leading to a degraded scenario.

Pasture degradation is a complex process that results in gradual decrease of the pasture's carrying capacity and culminates with its degradation. Degradation causes vary according to the specific situation of each biome, and may be classified as inadequate grazing and management practices, failures in pasture establishment, biotic factors (plagues and diseases), and abiotic factors (excess or lack of rain, low fertility, and insufficient soil drainage) ${ }^{3}$.

There is no uniform method to characterize pasture degradation indicators ${ }^{3}$. When considering animal productivity (meat and milk production, etc.) as a universal parameter to define pasture productivity, the pasture carrying capacity would be the most flexible indicator to quantify the degradation of a pasture. However, the author alerts that a priori it is not possible to guarantee the degradation condition of a pasture just by evaluating its carrying capacity.

*gustavo.bayma@embrapa.br; Phone 5519 3211-6200; www.embrapa.br/monitoramento-por-satelite

Remote Sensing for Agriculture, Ecosystems, and Hydrology XVIII, edited by

Christopher M. U. Neale, Antonino Maltese, Proc. of SPIE Vol. 9998, 99981C

(C) 2016 SPIE $\cdot$ CCC code: $0277-786 X / 16 / \$ 18 \cdot$ doi: $10.1117 / 12.2242043$

Proc. of SPIE Vol. $999899981 \mathrm{C}-1$ 
Thus, only by means of large-scale application of remote-sensing techniques will it be possible to dynamically characterize the status of pastures' plant cover, and to confirm or deny if the stocking rate parameter is a good indicator for pasture degradation levels. The approach of analyzing time series of satellite images is different from the traditional method of classifying and comparing images of a same scene at specific dates. This method has been widely employed to evaluate land-use changes, such as the increase of urban spots, the reduction of forest areas, and the conversion of pastures into agricultural crops ${ }^{4}$.

Several biophysical parameters, as the normalized difference vegetation index (NDVI) 5, 6, 7, 8, biomass ${ }^{9}$ and evapotranspiration ${ }^{10}$, and energy balance components ${ }^{11,12}$ has been used to characterize pasture grazing systems.

\subsection{Objective}

The objective of this work is to estimate biophysical parameters and energy balance components using the Simple Algorithm for Evapotranspiration Retrieving (SAFER) and the Monteith's light use efficiency (LUE) model, in two experimental pasture areas in the São Paulo State, Brazil.

\section{METHODOLOGY}

\subsection{Study are and dataset}

The study area is located at Pirassununga municipality, Sao Paulo State, in the Cerrado biome, with an average temperature of $23^{\circ} \mathrm{C}$ and annual rainfall of $1,300 \mathrm{~mm}$. According to Köppen-Geiger climate classification system, the local climate is temperate or subtropical hot-summer (Cwa), with dry winter/wet summer pattern. The pasture experimental area design has two different types of grazing system, rotational (RGS) and continuous (CGS) with 9.8 ha and 9.3 ha, with six and three paddocks, respectively (Figure 1). The rotational array consists of 7 days of ranching and 28 days of resting. Pasture specie is Urochloa brizantha cv. Marandu. Study area comprises the pasture experimental area and an area with wooded savanna (WS) vegetation (31.9 ha), used as reference to compare with the pasture area results.

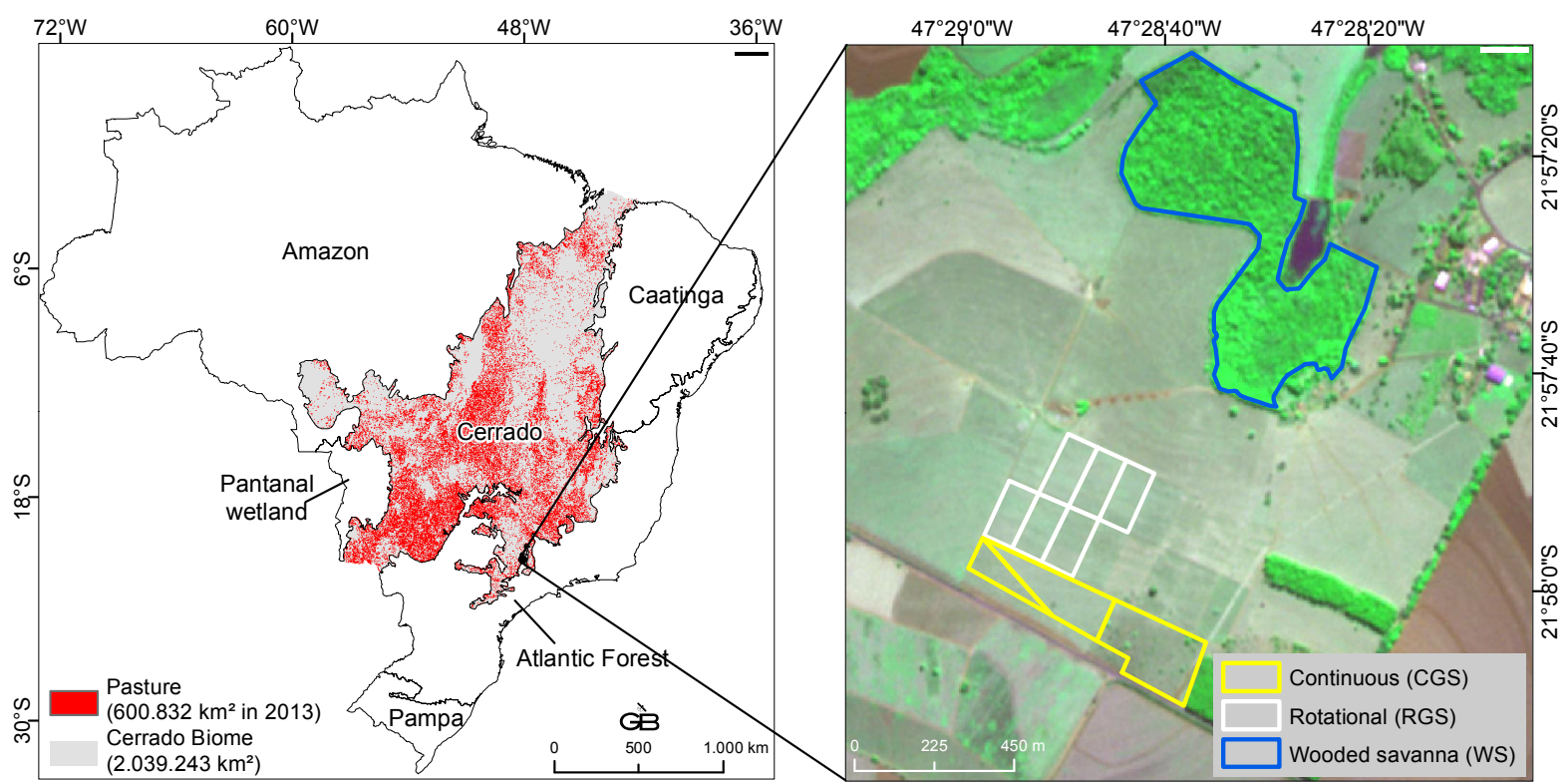

Figure 1. Cerrado Biome location in Brazil and pasture experimental area located at Pirassununga municipality, São Paulo State. Pasture mask data obtained at: http://www.dpi.inpe.br/tccerrado/result.htm. RapidEye image, RGB composite bands 3-5-2, from August $23^{\text {th }}, 2014$.

Landsat-8 images were obtained from "EarthExplorer" catalog from the US Geological Survey ${ }^{13}$. The aforementioned catalog provides "Level 1GT" images with systematic, radiometric ${ }^{14}$, and geometric accuracy, while employing a Digital Elevation Model (DEM) for topographic accuracy. This product uses reference data field (ground control points) and 
digital elevation data of the terrain to obtain the best possible accuracy of the land surface ${ }^{15}$. The list of all Landsat- 8 cloud-free images used in this work can be observed in Table 1, with 6 images from dry and 13 images from wet season.

Table1. Landsat-8 cloud-free images utilized. Day of the Year (DOY)

\begin{tabular}{|c|c|c|c|c|c|c|c|c|c|c|c|c|}
\hline \multirow{4}{*}{2013} & Month/Day & $5 / 19$ & $7 / 6$ & $8 / 23$ & $9 / 8$ & $10 / 10$ & $10 / 26$ & $11 / 11$ & $12 / 13$ & & & \\
\cline { 2 - 14 } & DOY & 139 & 187 & 235 & 251 & 283 & 299 & 315 & 347 & & & \\
\cline { 2 - 14 } & Season & Dry & Dry & Dry & Dry & Wet & Wet & Wet & Wet & & & \\
\hline \multirow{2}{*}{2015} & Month/Day & $1 / 1$ & $1 / 17$ & $4 / 23$ & $5 / 9$ & $5 / 25$ & $6 / 10$ & $6 / 26$ & $7 / 12$ & $7 / 28$ & $8 / 13$ & $8 / 29$ \\
\cline { 2 - 13 } & DOY & 1 & 17 & 113 & 129 & 145 & 161 & 177 & 193 & 209 & 225 & 241 \\
\cline { 2 - 12 } & Season & Wet & Wet & Dry & Dry & Dry & Dry & Dry & Dry & Dry & Dry & Dry \\
\hline
\end{tabular}

Global solar radiation $\left(\mathrm{R}_{\mathrm{G}}\right)$, air temperature $\left(\mathrm{T}_{\mathrm{a}}\right)$, and reference evapotranspiration $\left(\mathrm{ET}_{0}\right)$ from an agrometeorological station data located near the experimental area from the University of São Paulo (USP), Pirassununga campus (http://www.agrariasusp.com.br/agrariasusp01/estacao.html), were used together with the Landsat-8 images.

\subsection{The Simple Algorithm for Evapotranspiration Retrieving}

SAFER (Simple Algorithm for Evapotranspiration Retrieving) algorithm was applied together with the Monteith's Light Use Efficiency (LUE) model to estimate biomass and energy balance components. The remote sensing input parameters were surface albedo $\left(\alpha_{0}\right)$, surface temperature $\left(\mathrm{T}_{0}\right)$ and the Normalized Difference Vegetation Index (NDVI). The equations are described in details in Teixeira et al. ${ }^{16}$.

The broadband $\alpha_{p}$ was calculated as the total sum of the different narrow-band $\alpha p$ values according to the weights for each band $\left(\mathrm{w}_{\mathrm{b}}\right)$ :

$$
\alpha p=\Sigma w_{b} \alpha p_{b}
$$

where $\alpha p$ corresponds bands 1 to 7 for Landsat.

The thermal region from the Landsat sensor, the spectral radiance from the bands $10\left(\mathrm{~L}_{10}\right)$ and $11\left(\mathrm{~L}_{11}\right)$ was converted into radiometric temperatures applicable at the top of the atmosphere $\left(\mathrm{T}_{\mathrm{b}}\right)$ :

$$
T_{b}=\frac{K_{2}}{\ln \left(\frac{K_{1}}{L \lambda+1}\right)}-273.15
$$

where $\mathrm{K}_{1}$ and $\mathrm{K}_{2}$ are the conversion coefficients for TIRS/Landsat- 8 bands. $\mathrm{T}_{\mathrm{b}}$ values are the mean values calculated for bands 10 and 11 .

The results for the instantaneous $\alpha_{\mathrm{p}}$ and $\mathrm{T}_{\mathrm{b}}$ values were corrected atmospherically for acquiring the surface albedo $\left(\alpha_{0}\right)$ and surface temperature $\left(\mathrm{T}_{0}\right)$, by regression equations resulted from instantaneous field and satellite measurements in the study region.

Daily $\mathrm{R}_{\mathrm{n}}$ was estimated by using the Slob equation:

$$
R_{n}=\left(1-\alpha_{24}\right) R_{G}-a_{L} \tau_{s w}
$$

where $\alpha_{24}$ is daily surface albedo, $\mathrm{R}_{\mathrm{G}}$ is the global solar radiation the interpolated raster from meteorological station, $\mathrm{a}_{\mathrm{L}}$ is the net long wave radiation regression coefficient and $\tau_{\mathrm{sw}}$ is atmospheric transmissivity.

Daily surface albedo was estimated as:

$$
\alpha_{24}=a \alpha_{0}+b
$$

where, a e b are regression coefficients 1.023 e $0, .0149$, respectively. 
$a_{L}$ was spatially distributed through its relationship with $\mathrm{T}_{\mathrm{a}}$ :

$$
a_{L}=a T_{a}+b
$$

where, $\mathrm{a}$ and $\mathrm{b}$ are regression coefficients 6.99 and -39.93 , respectively.

The Normalized Difference Vegetation Index (NDVI):

$$
N D V I=\frac{\rho_{(N I R)}-\rho_{(R E D)}}{\rho_{(N I R)}+\rho_{(R E D)}}
$$

where $\rho_{\text {NIR }}$ and $\rho_{\text {RED }}$ represents surface reflectance in the near infrared (NIR) and red (RED) regions of the solar spectrum. For Landsat-8 this regions corresponds to the bands 5 and 4, respectively.

In SAFER algorithm, the ratio of actual $(\mathrm{ET})$ to the reference $\left(\mathrm{ET}_{0}\right)$ evapotranspiration - $\mathrm{ET}_{\mathrm{r}}$, was modelled at the satellite overpass time

$$
E T_{r}=\exp \left[a_{s f}+b_{s f}\left(\frac{T_{0}}{\alpha_{0} N D V I}\right)\right]
$$

where $\mathrm{ET}_{0}$ was calculated by the Penman-Monteith method ${ }^{17}$, and $\mathrm{as}_{\mathrm{f}}$ and $\mathrm{b}_{\mathrm{sf}}$ regression coefficients $1.8 \mathrm{e}-0.008$, respectively.

$\mathrm{ET}_{0}$ daily grids from the meteorological station were multiplied by the images resulted from Eq. 8, giving daily $\mathrm{ET}_{24}$ pixel values:

$$
\mathrm{ET}_{24}=\mathrm{ET}_{\mathrm{r}} * \mathrm{ET}_{0}
$$

The biomass production (BIO) was quantified as:

$$
B I O=\varepsilon_{\max } E_{f} A P A R 0,864
$$

where $\varepsilon_{\max }$ is the maximum light use efficiency, in this study was considered $2,15^{18}$, APAR is the fraction of absorbed photosynthetically active radiation, $\mathrm{E}_{f}$, is the evaporative fraction (no units) and 0.864 is a conversion factor.

The evaporative fraction $\left(\mathrm{E}_{f}\right)$, a soil moisture indicator, was quantified as ${ }^{19}$ :

$$
E_{f}=\frac{L E}{R_{n}-G}
$$

where $\lambda \mathrm{E}$ is the latent heat flux and $\mathrm{G}$ is soil heat flux.

For the daily soil heat flux $(\mathrm{G})$ values, the follow equation is used:

$$
\frac{G}{R_{n}}=a_{G}\left(b_{G} \alpha_{0}\right)
$$

where $\mathrm{a}_{\mathrm{G}}$ and $\mathrm{b}_{\mathrm{G}}$ are regression coefficients found to be 3.98 and -25.47 .

The heat loss rate to the air by convection and conduction, due temperature difference, is defined as sensible heat flux (H), estimated with SAFER as a net balance residue:

$$
H=R_{n}-\lambda E-G
$$

Statistical analysis was conducted in order to analyze pasture management impacts on biophysical and energy balance, where temporal average values were compared in order to assess significant difference between RGS and CGS areas. 


\section{RESULTS AND DISCUSSION}

\subsection{Climatological parameters}

Monthly cumulative rainfall in 2013 and 2015 is presented in Figure 2. These years had similar hydrological cycles, with $1,600 \mathrm{~mm}$ and 1,613 $\mathrm{mm}$ of cumulative rainfall, respectively. In wet season (September-March) average rainfall was $189.86( \pm 83.86)$ and $193.49( \pm 83.40) \mathrm{mm}$ and in dry season (April-August) was $70.60( \pm 43.27)$ and $49.08( \pm 21.97) \mathrm{mm}$ in 2013 and 2015, respectively. Figure 3 shows values for incident global radiation $\left(\mathrm{R}_{\mathrm{G}}\right)$, incident solar radiation at the top of the atmosphere $\left(\mathrm{R}_{\mathrm{A}}\right)$, air temperature $\left(\mathrm{T}_{\mathrm{a}}\right)$ and reference evapotranspiration $\left(\mathrm{ET}_{0}\right)$. As expected all climatological parameters present lower values in the 2015, dry season, DOY 139 to DOY 251, in 2013, and DOY 113 to DOY 241, in 2015 , and the peak was observed on January $17^{\text {th }}$, wet season.

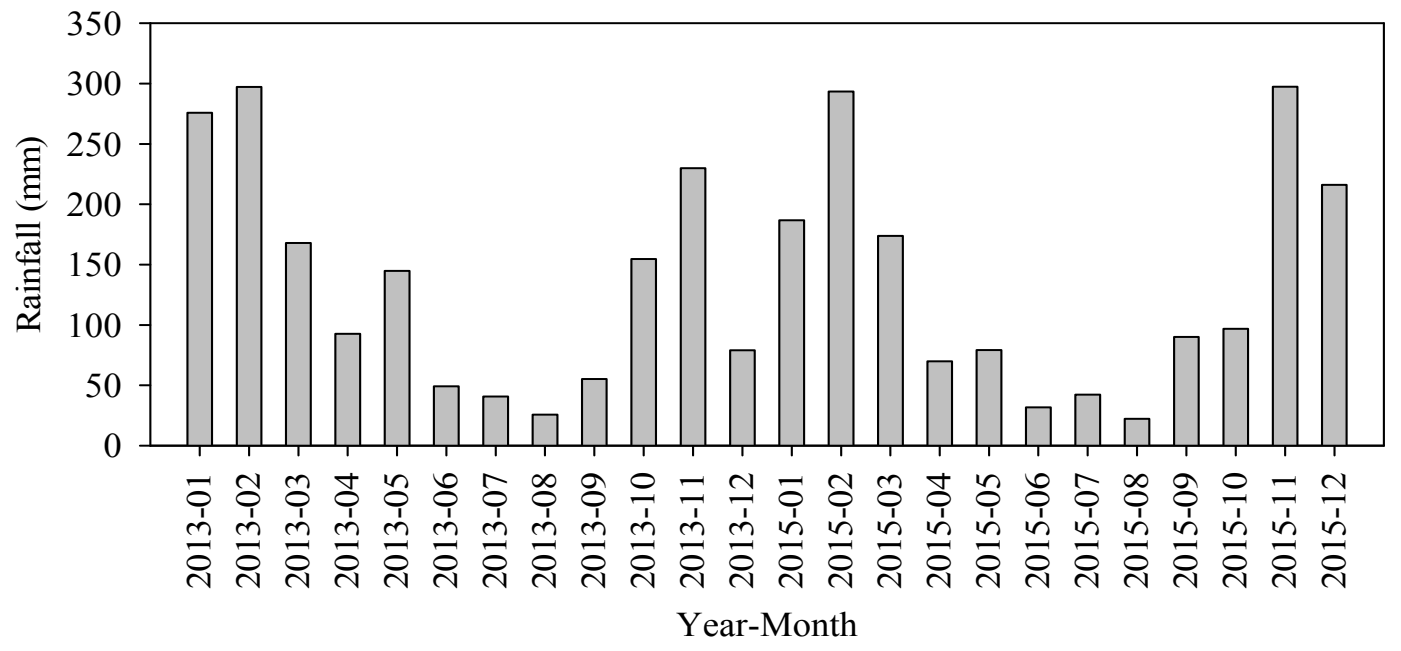

Figure 2. Study area monthly cumulative rainfall in 2013 and 2015.

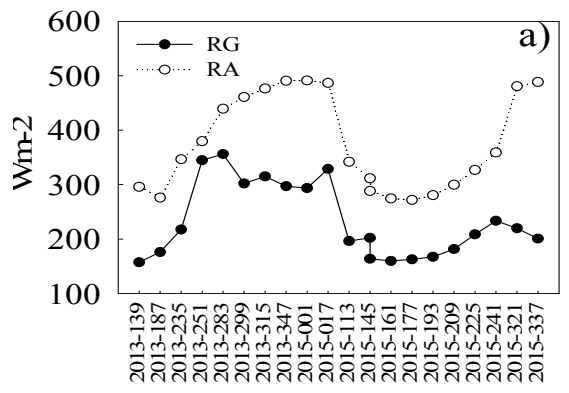

Year-DOY

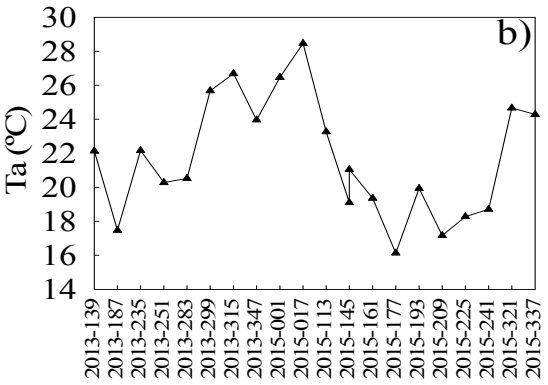

Year-DOY

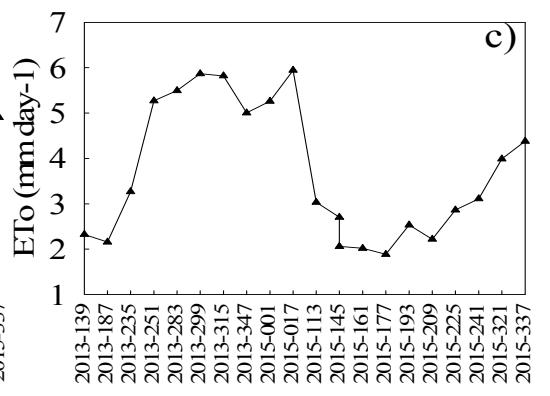

Year-DOY

Figure 3. Climatological parameters in values in 2013 and 2015: a) incident global radiation $\left(\mathrm{R}_{\mathrm{G}}\right)$ and incident solar radiation at the top of the atmosphere $\left(\mathrm{R}_{\mathrm{A}}\right)$; b) surface temperature $\left(\mathrm{T}_{\mathrm{a}}\right)$ and $\mathrm{c}$ ) evapotranspiration of reference $\left(\mathrm{ET}_{0}\right)$. Day of the Year (DOY)

\subsection{Biophysical parameters}

Figure 4 shows the temporal variability of NDVI from 2013 to 2015. WS NDVI values were relatively constant throughout the study period. As expected average NDVI values were higher in RGS $(0.76 ; \pm 0.08)$ than CGS $(0.60$; \pm 0.13 ) areas, $26.6 \%$ difference. RGS rotates the cattle between the available paddocks. In addition, WS presented higher values $(0.85 ; \pm 0.03)$ and this indicates higher resilience than pasture areas. T-test showed that normality test failed, thus Mann-Whitney test was performed. RGS and CGS difference is greater than would be expected by chance $(p<0.001)$.

RGS, CGS and WS average NDVI values were $0.74( \pm 0.11) 0.58( \pm 0.16)$ and $0.87( \pm 0.02)$ in the wet season (SeptemberMarch) and in the dry season (April-August) were $0.76( \pm 0.07), 0.61( \pm 0.11)$ and0.84 $( \pm 0.03)$, respectively. Pasture areas under intense cattle grazing and dry conditions have fewer green leaves and is dominated by nonphotosynthetic materials (litter, dry stems and dry leaves). The lowest average NDVI value observed for CGS was 0.35, in DOY 283 (2013), and for RGS was 0.59 ; a percentage difference of $69 \%$. 


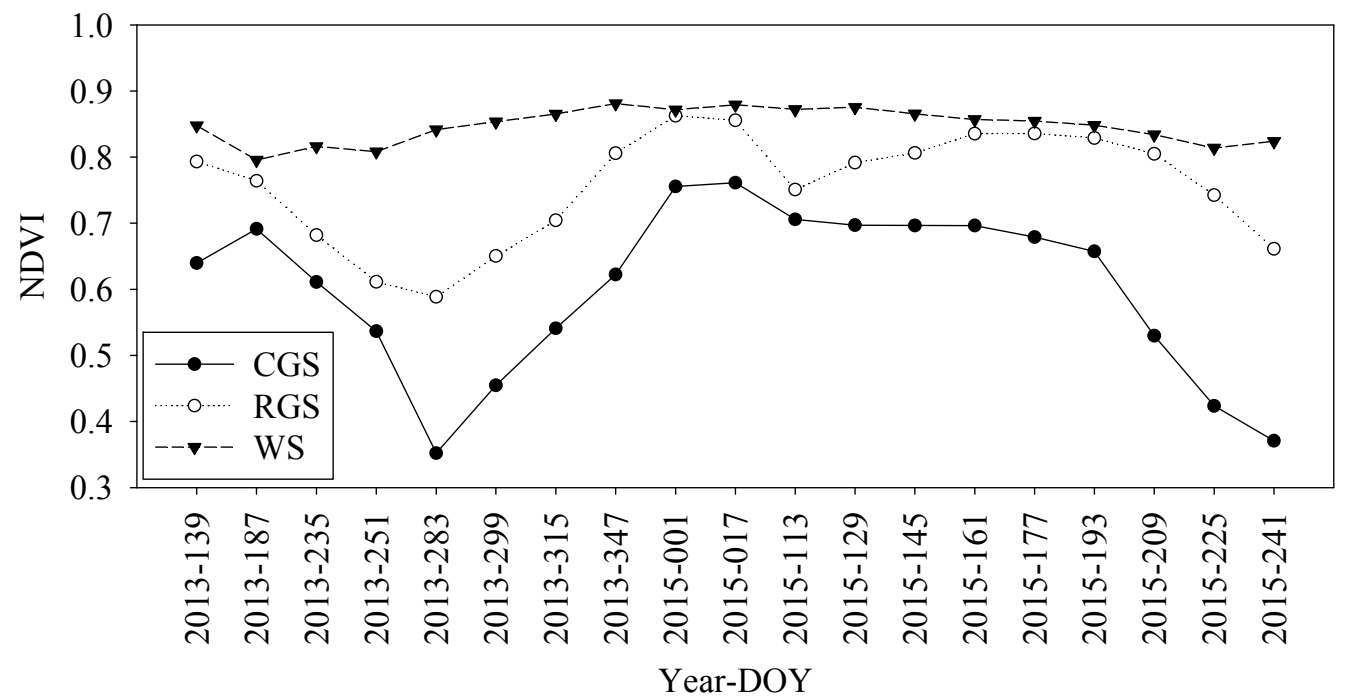

Figure 4. NDVI average values for rotation grazing system (RGS), continuous grazing system (CGS) and wooded savanna (WS) areas in 2013 and 2015. Day of the Year (DOY).

Average biomass and daily evapotranspiration $\left(\mathrm{ET}_{24}\right)$ temporal average values are presented in Figure $5 \mathrm{a}$ and $5 \mathrm{~b}$. As expected, similarly to NDVI values, average biomass and $\mathrm{ET}_{24}$ values were higher in RGS than CGS during the study period, $63.01 \mathrm{~kg} \mathrm{ha}^{-1} \mathrm{day}^{-1}( \pm 32.69)$ and $30.93 \mathrm{~kg} \mathrm{ha}^{-1}$ day $^{-1}( \pm 24.78)\left(103.7 \%\right.$ of difference) and $1.55 \mathrm{~mm}^{-1} \mathrm{yy}^{-1}( \pm 0.65)$ and $0.95 \mathrm{~mm} \mathrm{day}^{-1}( \pm 0.62)\left(63.15 \%\right.$ of difference), respectively. WS presented $76.71 \mathrm{~kg} \mathrm{ha}^{-1} \mathrm{day}^{-1}( \pm 26.31)$ and $1.76 \mathrm{~mm}$ $\operatorname{day}^{-1}( \pm 0.58)$, for biomass and $\mathrm{ET}_{24}$, respectively. For biomass and $\mathrm{ET}_{24}$, T-test showed that normality test failed, thus Mann-Whitney test was performed. RGS and CGS difference is greater than would be expected by chance $(p<0.001)$.

RGS, CGS and WS average biomass values were $70.3 \mathrm{~kg} \mathrm{ha}^{-1}$ day $^{-1}( \pm 50.8), 30 \mathrm{~kg} \mathrm{ha}^{-1}$ day $^{-1}( \pm 36.6)$ and $101 \mathrm{~kg} \mathrm{ha}^{-1}$ day $^{-}$ ${ }^{1}( \pm 24.5)$ in the wet season (September-March) and in the dry season (April-August) were $62 \mathrm{~kg} \mathrm{ha}^{-1}$ day $^{-1}( \pm 21.3), 33.8$ $\mathrm{kg} \mathrm{ha}^{-1}$ day $^{-1}( \pm 17.7)$ and $66.6 \mathrm{~kg} \mathrm{ha}^{-1}$ day $^{-1}( \pm 19.1)$. For ET $24, \mathrm{RGS}$, CGS and WS average values were $2.10 \mathrm{~mm} \mathrm{day}^{-1}$ ( \pm 0.92$), 1.21 \mathrm{~mm} \mathrm{day}^{-1}( \pm 0.96)$ and $2.49 \mathrm{~mm} \mathrm{day}^{-1}( \pm 0.42)$ and in the dry season (April-August) were $1.3 \mathrm{~mm} \mathrm{day}^{-1}$ $( \pm 0.24), 0.83 \mathrm{~mm}_{\text {day }}{ }^{-1}( \pm 0.38)$ and $1.44 \mathrm{~mm}_{\text {day }}{ }^{-1}( \pm 0.27)$, respectively. Biomass and $\mathrm{ET}_{24}$ values in RGS were higher than CGS. This is likely due to paddocks management, with the 28 days of resting.

Similar behavior were found on biomass and $\mathrm{ET}_{24}$ estimative in pasture areas, as these biophysical properties are strongly related to grazing intensity ${ }^{11,20}$. Differences in ET values are more significant during the water stress period, and the values were up to $14.8 \%$ and $59.2 \%$ smaller in pastures featuring moderate and strong degradation respectively ${ }^{10}$. 

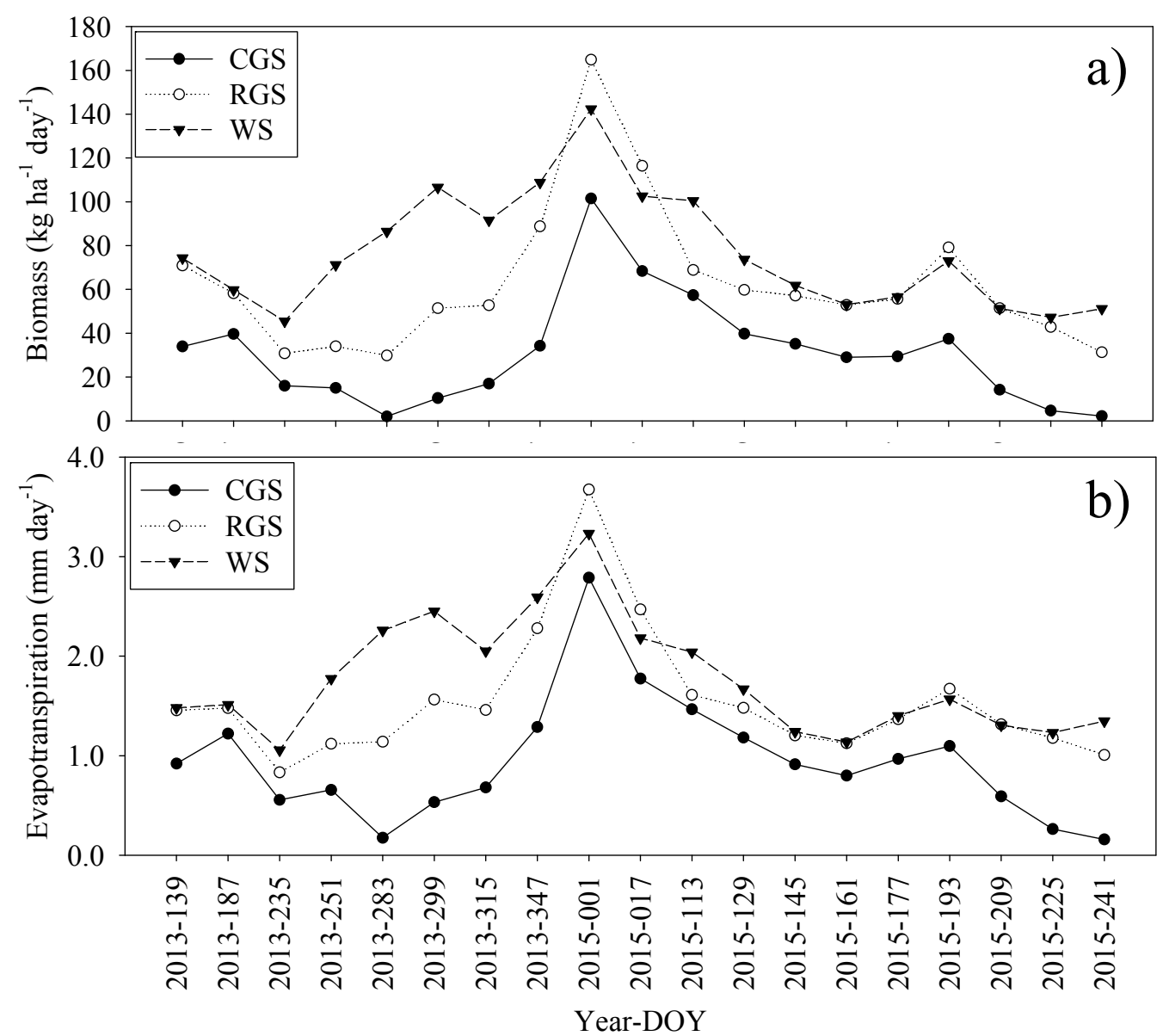

Figure 5. Biomass (a) and evapotranspiration $\left(\mathrm{ET}_{24}\right)(\mathrm{b})$ average values for rotation grazing system (RGS), continuous grazing system (CGS) and wooded savanna (WS) areas in 2013 and 2015. Day of the Year (DOY).

\subsection{Energy balance components}

Figure $6 \mathrm{a}, 6 \mathrm{~b}$ and $6 \mathrm{c}$ shows temporal energy balance components, latent heat flux $(\lambda \mathrm{E})$, Sensible heat flux $(\mathrm{H})$ and soil heat flux (G). T-test showed that normality test failed, thus Mann-Whitney test was performed for all components. $\lambda \mathrm{E}$ was the energy balance component which had a significant difference $(p<0.001)$ between RGS and CGS throughout the studied period.

$\lambda \mathrm{E}$, defined as the surface heat associated with evaporation of water, temporal average values are presented in Figure $6 \mathrm{a}$. RGS, CGS and WS average $\lambda \mathrm{E}$ values were $5.14 \mathrm{MJ} \mathrm{m}^{-2}$ day $^{-1}( \pm 2.26), 2.96 \mathrm{MJ} \mathrm{m}^{-2} \mathrm{day}^{-1}( \pm 2.36)$ and $6.03 \mathrm{MJ} \mathrm{m}^{-2} \mathrm{day}^{-1}$ $( \pm 1.04)$ in the wet season (September-March) and in the dry season (April-August) were $3.17 \mathrm{MJ} \mathrm{m}^{-2} \mathrm{day}^{-1}( \pm 0.60), 2.03$ $\mathrm{MJ} \mathrm{m}^{-2} \mathrm{day}^{-1}( \pm 0.93)$ and $3.53 \mathrm{MJ} \mathrm{m}^{-2} \mathrm{day}^{-1}( \pm 0.67)$. Throughout the studied period RGS and CGS average values were $3.79 \mathrm{MJ} \mathrm{m}^{-2}$ day $^{-1}( \pm 1.59)$ and $2.32 \mathrm{MJ} \mathrm{m}^{-2}$ day $^{-1}( \pm 1.52), 63 \%$ of difference. The amount of $\mathrm{R}_{\mathrm{n}}$ partitioned to $\lambda \mathrm{E}$ will be higher in vegetated surfaces than surfaces with less canopy cover.

$\mathrm{H}$, defined as the process where the heat energy is transferred from the surface to the atmosphere by conduction and convection, temporal average values are presented in Figure 6b. Throughout the studied period RGS and CGS average values were $6.37 \mathrm{MJ} \mathrm{m}^{-2}$ day $^{-1}( \pm 3.43)$ and $7.83 \mathrm{MJ} \mathrm{m}^{-2}$ day $^{-1}( \pm 3.86), 22.91 \%$ of difference. RGS, CGS and WS average $\mathrm{H}$ values were $8.86 \mathrm{MJ} \mathrm{m}^{-2} \mathrm{day}^{-1}( \pm 3.49), 11.05 \mathrm{MJ} \mathrm{m}^{-2}$ day $^{-1}( \pm 3.59)$ and $7.66 \mathrm{MJ} \mathrm{m}^{-2}$ day $^{-1}( \pm 2.15)$ in the wet season (September-March) and in the dry season (April-August) were $5.22 \mathrm{MJ} \mathrm{m}^{-2}$ day $^{-1}( \pm 2.84), 6.34 \mathrm{MJ} \mathrm{m}^{-2}$ day $^{-1}( \pm 3.07)$ and $4.56 \mathrm{MJ} \mathrm{m}^{-2}$ day $^{-1}( \pm 2.35)$, respectively.

$\mathrm{G}$, defined as the energy utilized in heating the soil, temporal average values are presented in Figure 6c. RGS, CGS and WS average $G$ values were $1.25 \mathrm{MJ} \mathrm{m}^{-2}$ day $^{-1}( \pm 0.11), 1.18 \mathrm{MJ} \mathrm{m}^{-2}$ day $^{-1}( \pm 0.15)$ and $2.06 \mathrm{MJ} \mathrm{m}^{-2}$ day $^{-1}( \pm 0.29)$ in the wet season (September-March) and in the dry season (April-August) were $0.77 \mathrm{MJ} \mathrm{m}^{-2}$ day ${ }^{-1}( \pm 0.13), 0.84 \mathrm{MJ} \mathrm{m}^{-2}$ day $^{-1}$ 
$( \pm 0.16)$ and $1.46 \mathrm{MJ} \mathrm{m}^{-2}$ day $^{-1}( \pm 0.40)$, respectively. Throughout the studied period, RGS and CGS average values were $0.92 \mathrm{MJ} \mathrm{m}^{-2}$ day $^{-1}( \pm 0.26)$ and $0.95 \mathrm{MJ} \mathrm{m}^{-2}$ day $^{-1}( \pm 0.22), 3.26 \%$ of difference. Similar results when comparing moderately and heavily grazed pasture areas were found in North Dakota, USA. $\lambda E$ average values were higher in moderately grazed pasture than heavily grazed and $\mathrm{H}$ average values were higher in heavily grazed pastures than moderately grazed ${ }^{12}$.
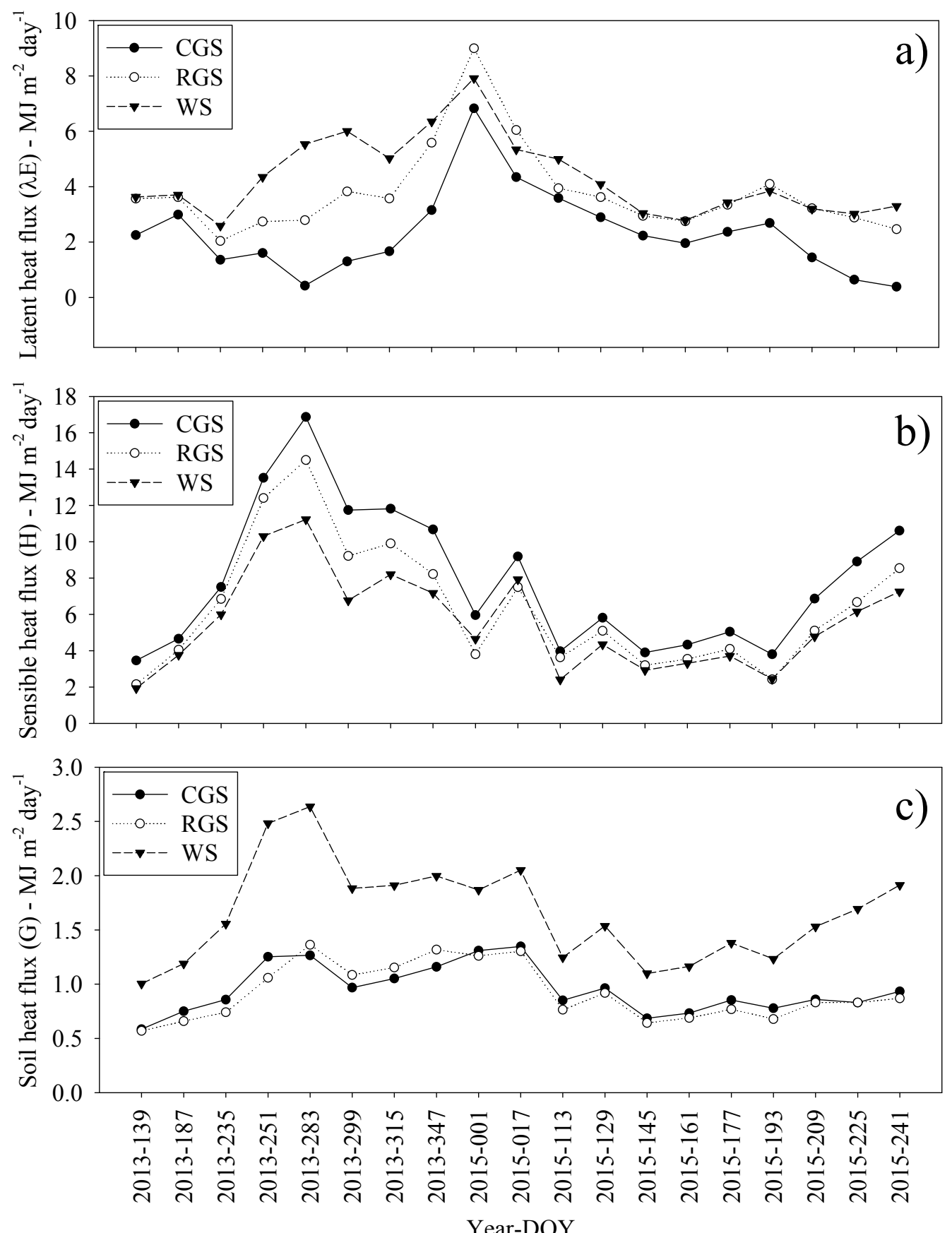

Figure 6. Latent heat flux (a), sensible heat flux (b) and soil heat flux (c) temporal average values for rotation grazing system (RGS), continuous grazing system (CGS) and wooded savanna (WS) areas in 2013 and 2015. Day of the Year (DOY). 


\section{CONCLUSIONS}

SAFER is a feasible tool to estimate biophysical parameters and energy balance components in pasture area and shows potential to discriminate continuous and rotational grazing systems in time-series analysis. Grazing systems influence biophysical parameters and energy partition components. The results indicated that RGS have higher biomass, greenness and evapotranspiration. RGS benefits the microclimate, due higher $\lambda \mathrm{E}$ values. On the other side, CGS estimated parameters behavior, which characterizes unfavorable conditions for biomass production, shows potential to indicate degradation processes pastures areas. We recommend that future studies validate the estimated data using in situ parameters for subsequent large-scale applications.

\section{ACKNOWLEDGEMENTS}

The PECUS Network, Greenhouse gases (GHG) dynamics in Brazilian livestock production systems.

\section{REFERENCES}

[1] MMA. Brasil. Ministério do Meio Ambiente, [Mapeamento do uso e cobertura do Cerrado: Projeto TerraClass Cerrado 2013], Brasília: MMA, 1-69 (2015).

[2] MMA. Brasil. Ministério do Meio Ambiente, [Mapeamento de cobertura vegetal do bioma Cerrado], Brasília: MMA, 1-93 (2007).

[3] Dias-Filho, M. B, [Diagnóstico das pastagens no Brasil], Embrapa Amazônia Oriental, 1-36 (2014).

[4] Lu, D., Mausel, P., Brondízio, E., Moran, E., "Change detection techniques," International Journal of Remote Sensing 25(12), 2365-2407 (2004).

[5] Hill, M. J., Donald, G. E., Vickery, P. J., Smith, R. C. G., "NDVI-based phonological indices; predictive potential for grazing systems," Proc. for the 9th Australasian Remote Sensing and Photogrammetry Conference, UNSW, Sydney, (1998).

[6] Numata, I., Roberts, D. A., Chadwick, O. A., Schimel, J., Sampaio, F. R., Leonidas, F. C., Soares, J. V., "Characterization of pasture biophysical properties and the impact of grazing intensity using remotely sensed data," Remote Sensing of Environment 109, 314-327 (2007).

[7] Andrade, R. G., Teixeira, A. H. de C., Leivas, J. F., Silva, G. B., Nogueira, S. F., Victoria, D. C., Vicente, Bolfe, E. L., "Indicativo de pastagens plantadas em processo de degradação no bioma Cerrado," Proc. Brazilian Symposium on Remote Sensing 1585-1592 (2015).

[8] Andrade, R. G. Bolfe, E. L., Victoria, D. C., Nogueira, S. F., "Recuperação de pastagens no Cerrado," Agroanalysis 36(2) 30-32 (2016).

[9] Todd, S. W., Hoffer, R. M., Milchunas, D. G., "Biomass estimation on grazed and ungrazed rangelands using spectral indices," International Journal of Remote Sensing 19, 427-438 (1998).

[10] Andrade, R. G, Teixeira, A. H. de C, Sano, E. E., Leivas, J. F, Victoria, D. C., Nogueira, S. F., "Pasture evapotranspiration as indicators of degradation in the Brazilian Savanna. A case study for Alto Tocantins watershed," Proc. SPIE 9239 (2014).

[11] Pôças, I.; Cunha, M.; Pereira, L. S.; Allen, R. G., "Using remote sensing energy balance and evapotranspiration to characterize montane landscape vegetation with focus on grass and pasture lands," International Journal of Applied Earth Observation and Geoinformation 21, 159-172 (2013).

[12] Melesse, A. M., Frank, A., Nangia, V., Hanson, J., "Analysis of energy fluxes and land surface parameters in a grassland ecosystem: a remote sensing perspective," International Journal of Remote Sensing 29, 3325-3341 (2008).

[13] U.S. GEOLOGICAL SURVEY, "EarthExplorer”, 20 January 2016, <http://earthexplorer.usgs.gov/> (2016).

[14] Vermote, E., Justice, C., Claverie, M., Franch, B., "Preliminary analysis of the performance of the Landsat 8/OLI land surface reflectance product," Remote Sensing of Environment. In press (2016).

[15] U.S. GEOLOGICAL SURVEY. "Product guide: provisional Landsat 8 surface reflectance product". Virginia: Department of the Interior, USGS, pg23 (2016).

[16] Teixeira, A. H. de C.; Hernandez, F. B. T.; Lopes, H. L.; Scherer-Warren, M.; Bassoi, L. H., [A Comparative Study of Techniques for Modeling the Spatiotemporal Distribution of Heat and Moisture Fluxes in Different Agroecosystems in Brazil]. In: George G. Petropoulos. (Org.). Remote Sensing of Energy Fluxes and Soil Moisture Content. 1ed.Boca Raton, Florida: CRC Group, Taylor and Francis, 169-191 (2014).

[17] Allen, R. G., Pereira, L. S., Raes, D., Smith, M., [Crop Evapotranspiration: Guidelines for Computing Crop Water Requirements], Food and Agriculture Organization of the United Nations: Rome, Italy (1998). 
[18] Bastiaanssen, W. G. M.., Ali, S., "A new crop yield forecasting model based on satellite measurements applied across the Indus Basin, Pakistan," Agric. Ecosyst. Environ. Amsterdam 94(3), 321-340 (2003).

[19] Teixeira, A. H. de C., Leivas, J. F., Andrade, R. G.., Hernandez, F. B. T., "Water productivity assesments with Landsat 8 images in the Nilo Coelho irrigation scheme," Irrig. Botucatu, 1-10, Botucatu (2015).

[20] Boschetti, M., Bocchi, S., Brivio, P. A., "Assessment of pasture production in the Italian Alps using spectrometric and remote sensing information," Agric. Ecosyst. Environ. 118, 267-272 (2007). 